\title{
Ground-dwelling arthropod assemblages of partially improved heathlands according to the species of grazer and grazing regime
}

\author{
Rocío ROSA GARCÍA, URCESINo GARCÍA, Koldo OSORO and RAFAEL CELAYA
}

\begin{abstract}
Servicio Regional de Investigación y Desarrollo Agroalimentario (SERIDA), Apdo. 13, 33300 Villaviciosa, Asturias, Spain; e-mail: entomteam@hotmail.com
\end{abstract}

Key words. Ground-dwelling arthropods, grazing, cattle, sheep, goats, grassland, shrubland

\begin{abstract}
The creation of improved areas is one way of increasing the productivity of livestock on Cantabrian heathland (NW Spain), a habitat that is frequently located in less favourable mountainous areas where the development of sustainable husbandry is limited. The effect of this on the biodiversity of heathland is unclear and likely to depend on several factors, such as the grazing regime. In order to clarify this situation, the effects of type of vegetation, species of grazer and grazing regime on the composition of the ground-dwelling arthropod fauna of partially improved heathland were determined. The effects of grazing by cattle or sheep and two grazing regimes (cattle or sheep, or both of them together with goats) were studied in eight plots (two replicates per treatment). Each plot included two types of vegetation, gorse (Ulex gallii)-dominated shrubland and improved grassland (Lolium perenneTrifolium repens). Arthropods were surveyed using pitfall traps. Overall, the composition of the arthropod fauna did not differ between plots grazed by different species of grazer or using different grazing regimes but was significantly associated with the type of vegetation. Most of the opilionids and several carabids clearly preferred shrubland, while lycosids and various carabids were mainly associated with grassland. While the species of grazer affected the faunal composition of grassland, grazing regime was more important in shrubland. Arthropod responses to the grazing treatments were determined by the grazing behaviour of the large herbivores and the habitat requirements of each arthropod taxon. The great structural heterogeneity of the vegetation and the more microhabitats in shrubland grazed by mixed flocks was mainly a result of the goats preferring to browse on the woody vegetation in these areas. The grazing by either sheep or cattle had less of an affect on the fauna of shrubland than grassland.
\end{abstract}

\section{INTRODUCTION}

Rural Europe is characterized by a great diversity of cultural landscapes of high nature-conservation value, shaped by traditional land-use systems (Bignal, 1998; Ostermann, 1998), which support high levels of biodiversity. However, many traditional ways of using land have ceased or are now less common than a few decades ago as a result of the shift in land use towards either extensification and land abandonment or intensification (Plieninger et al., 2006). Furthermore, despite recent agricultural policies placing a greater emphasis on environmental benefits rather than only maximizing production, their success in ameliorating the reduction in biodiversity remains unclear (Kleijn et al., 2006).

The decline in the traditional practice of grazing heathland during the 20th century is considered to be one of the major causes of the progressive loss of heathland in Europe (Webb, 1990; Marrs \& Britton, 2000) and a threat to their associated faunas (Rose et al., 2000). Cantabrian heathland cover a wide area in the northern Iberian Peninsula, accounting for $21 \%$ of the area of Asturias (Álvarez et al., 2004) and are frequently less-favoured areas traditionally used to graze livestock. The sustainability of such systems is constrained by the low nutritive value of the woody vegetation of heathland (Osoro et al., 2007) however the partial transformation of heathland into improved pasture is one way of improving the socio-economic situation in these areas (Sineiro et al., 1984). Nevertheless, the effectiveness of these grazing systems depends on many factors, among which the species of grazer and flock structure might be crucial. The consequences for vegetation dynamics and animal production in partially improved heathland have been evaluated (Celaya et al., 2007, 2008; Benavides et al., 2009). In contrast, information on the cascading effects on the local fauna is clearly lacking, even though it is known that the transformation of native systems into pasture or cropping land may result in considerable changes in the arthropod communities (Decaens et al., 2004), which might also differ depending on the species of grazer (Dennis et al., 1997; Rosa García et al., 2010) or grazing regime (Dennis, 2003; Dennis et al., 2008).

Arthropods should be an integral part of any scheme monitoring biodiversity (Cameron et al., 2004) as many of them are very sensitive to environmental change (Rainio \& Niemelä, 2003). They are abundant and easily sampled and unlike larger or more mobile animals, their presence can be a better indicator of the suitability of an area for supporting a viable population of the group being studied (Bromham et al., 1999). Wolf spiders (Araneae, Lycosidae), harvestmen (Opiliones) and ground beetles (Coleoptera: Carabidae), in particular, are regarded as good bioindicators of habitat change (e.g. Kremen, 1992; Kremen et al., 1993; Rainio \& Niemelä, 2003; Cardoso et al., 2004; Komposch, 2004; Pearce \& Venier, 2006) and can be used to evaluate differences in biodiversity between areas subjected to different types of management (e.g. Niemelä, 2000; Bromham et al., 1999). 
The aim of this study was therefore to investigate whether the composition of ground-dwelling arthropods (focusing on wolf spiders, harvestmen and ground beetles) differed between: (a) vegetation types (heathlands or improved areas), (b) grazer species (cattle or sheep) and (c) grazing regimes (single or mixed grazing with goats) in heathland areas, which had been partially converted into perennial ryegrass-white clover grassland.

The results of this study on the arthropod fauna, together with those on vegetation and livestock performance, will be used to determine the extent to which the management strategies studied can provide sustainable alternatives for managing partially improved heathland in marginal areas from both environmental and productive points of view.

\section{MATERIAL AND METHODS}

\section{Study site and experimental design}

The current investigation was carried out at the Carbayal Research Station located in Illano, Asturias, NW Spain $\left(43^{\circ} 20^{\prime} \mathrm{N}, 6^{\circ} 53^{\prime} \mathrm{W}\right)$, at $950-1000 \mathrm{~m}$ a.s.l. Its climate is typically oceanic with an average annual rainfall of $1536 \mathrm{~mm}$ and mean temperature of $10.0^{\circ} \mathrm{C}$. The soils are acidic ( $\mathrm{pH}$ around 4$)$ and deficient in nutrients such as phosphorus, calcium and magnesium. Natural vegetation is composed of heathland dominated by species of heather such as Erica umbellata L., Erica cinerea L. and Calluna vulgaris (L.) Hull and gorse (Ulex gallii Planchon), a thorny woody legume, while the most abundant herbaceous species are grasses such as Pseudarrhenatherum longifolium (Thore) Rouy and Agrostis curtisii Kerguélen.

In 2001 a west-facing slope covered with heathland was mechanically cleared and partly sown with perennial ryegrass (Lolium perenne L.) and white clover (Trifolium repens L.). Then it was divided into eight adjacent fenced plots (0.9-2.7 ha). Within each plot, one third of the area consisted of improved grassland and the other two thirds of cleared shrubland. The plots were linearly arranged across the hillside and grouped in two blocks, reflecting a difference in the rockiness of terrain on the two halves of the hillside. A factorial design of two species of grazer species (cattle or sheep) and two grazing regimes (grazing by single species or by mixed flocks with goats) with two replicates was established from 2002 to 2008 . Species of grazer and grazing regime were the whole-plot factors while the type of vegetation (grassland or shrubland) was the split-plot factor.

Asturiana de los Valles beef cows with their winter-born calves or yearling bulls grazed at a stocking rate of approximately 1.1 lactating cows per hectare or $1.5-1.7$ yearling bulls per hectare. There was a ratio 1 cow to 7 goats in mixed flocks. Gallega sheep and Cashmere goats, with their lambs and kids, grazed at a stocking rate of 10 breeding females per hectare and in mixed flocks the ratio was $1: 1$. The weight of every animal was determined and they were randomly assigned to each plot depending on the treatment and the grazing season, which extended from April-May to October-November [see Benavides et al. (2009) for more details].

The vegetation was measured at the beginning of the grazing season in 2008 in the shrubland areas, using the point-quadrat technique (Grant, 1981) and recording 500 contacts per plot. Gorse was the dominant plant in all plots, with cover percentages ranging from $53 \%$ and $61 \%$ in the plots grazed by mixed flocks of sheep + goats and cattle + goats, respectively, to $68 \%$ and $66 \%$ in those grazed by sheep and cattle, respectively. Herbaceous cover in the plots subjected to mixed grazing $(34 \%$

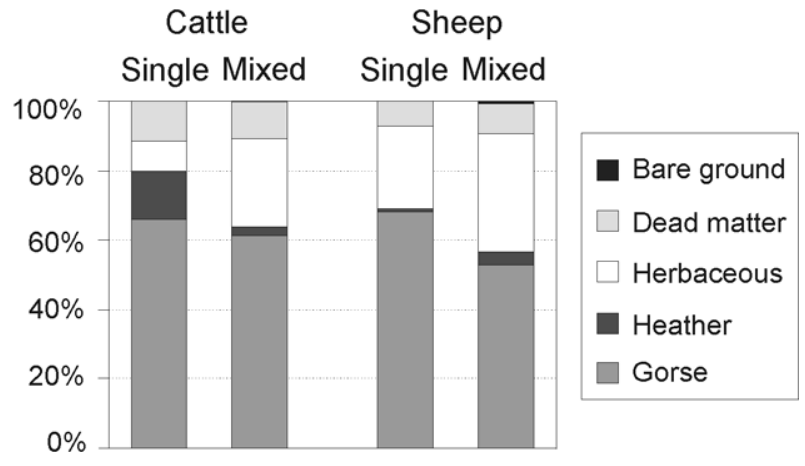

Fig. 1. Percentage of cover in cleared heathland grazed by either cattle or sheep, or mixed flocks with goats, in 2008. Means are for two plots per treatment.

when grazed by sheep + goats and $25 \%$ by cattle + goats) was greater than in those grazed by a single species $(23 \%$ when grazed by sheep and $9 \%$ by cattle). Heather cover ranged from only $0.8 \%$ when grazed only by sheep, $2.9-3.5 \%$ when grazed by mixed flocks, to a maximum of $13.6 \%$ when grazed only by cattle. The remainder of the cover consisted of $7.5-11.7 \%$ dead matter and bare ground (Fig. 1).

\section{Arthropod sampling}

Arthropods were sampled during 2008 using pitfall traps that consisted of plastic cups $10 \mathrm{~cm}$ in diameter and $13 \mathrm{~cm}$ deep. They were placed in rows of 6 traps $4 \mathrm{~m}$ apart within each type of vegetation (shrubland or grassland) in each plot. The brims of the traps were flush with surface of the ground and protected from trampling and flooding by a tile. Each trap was filled with $200 \mathrm{cc}$ of a solution of water and ethylene glycol. Traps operated continuously from mid July to mid September and were emptied every second week.

Adult specimens of wolf spiders (Araneae: Lycosidae), harvestmen (Opiliones) and ground beetles (Coleoptera: Carabidae) were identified to species or the lowest possible taxonomic level using standard keys. Nomenclature follows Platnick (2006) for wolf spiders, Rambla (1998) for Opiliones, and Ortuño \& Marcos (2003) for Carabidae.

\section{Statistical analysis}

The responses of arthropod assemblages to the treatments were analyzed using the partial redundancy analysis (RDA) in CANOCO version 4.5 (ter Braak \& Šmilauer, 2002). The appropriateness of this method was based on the length of the main gradient (2.206) in the data, which was estimated using detrended correspondence analysis. The abundance data pooled over the whole sampling period was $\log _{10}(\mathrm{x}+1)$ transformed and rare species were down-weighted. The experimental factors (species of grazer, grazing regime and type of vegetation) were considered to be the environmental categorical variables and coded as dummy variables. To estimate the significance of the differences between treatments, Monte-Carlo tests with 4999 permutations under reduced model were used (Lepš \& Šmilauer, 2003). The effects of those environmental variables that varied among the whole-plots (species of grazer and grazing regime) were tested by permuting whole-plots completely at random while keeping the split-plots of each whole-plot together. When testing for variations within whole-plots, split-plots (type of vegetation) were permuted without permuting whole-plots. The interactions between species of grazer or grazing regime and type of vegetation were evaluated using unrestricted permutations. When the interaction was significant, RDA analyses were used for each type of vegetation separately in order to determine 
the effects of both grazing treatments and the interaction between them.

Whenever significant responses of the faunal assemblages to the treatments were recorded, SIMPER analyses (Clarke \& Warwick, 2001) were performed using the PRIMER 5 software package (Clarke \& Gorley, 2001) to investigate the role of individual species in the separation between treatments. The similarity percentages routine of the SIMPER decomposes average Bray-Curtis dissimilarities between all pairs of samples into the percentage contributions of each species. Species that are abundant within groups are those that contribute most to the similarity within groups. The original abundance data matrix was $\log _{10}(x+1)$ transformed. This analysis results in the rare species contributing less to the overall pattern (Clarke \& Warwick, 2001). The SIMPER analysis takes into consideration the actual dissimilarities and not the approximation represented by a twodimensional ordination, and provides a better interpretation of the established group structures (Clarke \& Gorley, 2001).

\section{RESULTS}

A total of 10,377 arthropods were recorded, of which 375 were wolf spiders (Araneae: Lycosidae) belonging to 6 species, 702 harvestmen (Opiliones) belonging to 10 species and 459 beetles (Coleoptera: Carabidae) belonging to 22 species, were included in the multivariate analyses (see appendix for details of the species).

The RDA analyses associated most of the variation in the composition of the fauna with the type of vegetation $(P<0.01$, Table 1). More species of arthropods, including most of the harvestmen and large carabids (e.g. Carabus spp.), were caught in shrubby vegetation, whereas a few species, including spiders that prefer open areas, like Pardosa pullata (Clerck, 1758) or Alopecosa pulverulenta (Clerck, 1757) (Harvey et al., 2002; Oxbrough et al., 2006) and smaller herbivorous carabids (e.g. Calathus spp., Amara sp.), were more abundant in the improved grassland. The SIMPER analysis indicated that the main differences in the composition in the fauna caught in the different types of vegetation were attributed to a set of species (average dissimilarity $=64.8 \%$ ) that were more abundant in gorse-dominated shrubland, such as the harvestmen Nemastoma hankiewiczii (Kulczynski, 1909) (11.8\%), Homalenotus quadridentatus (Cuvier, 1795) (8.8\%), Sabacon franzi Roewer, 1953 (8.5\%) and Odiellus spinosus (Bosc, 1792) (6.4\%), the ground bee-

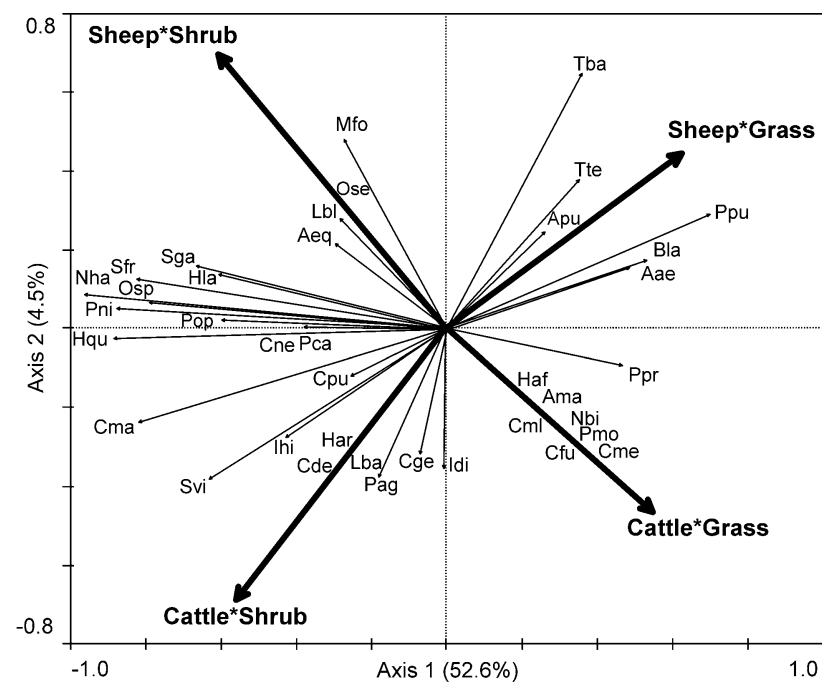

Fig. 2. RDA ordination diagram showing the interaction between species of grazer (cattle or sheep) and type of vegetation (shrubland or grassland) and their effect on arthropod assemblages. For species abbreviations see appendix.

tles Carabus macrocephalus Dejean, 1826 (6.7\%) and Steropus gallega (Fairmaire, 1859) (5.4\%), and the wolf spider Pardosa nigriceps (Thorell, 1856) (6.6\%).

The species composition of the ground-dwelling arthropods was not significantly associated with either the species of grazer or the grazing regime. On the other hand, the interaction between species of grazer and type of vegetation was significant $(P<0.01$, Table 1$)$. After forward selection, grassland vegetation grazed by cattle $(F=$ 9.67, $P<0.001)$ or sheep $(F=3.94, P=0.028)$ accounted for most of the variation in faunal assemblages $(52.5 \%$ of the variance in species data). Although certain species seemed to be associated with either sheep or cattle, most of the fauna was not associated with a particular species of grazer in shrubland, whereas clear associations with cattle [e.g. Pardosa monticola (Clerck, 1758) and Calathus spp.] or sheep grazed sites [e.g. P. pullata and Trochosa terricola (Thorell, 1856)] were recorded in grassland (Fig. 2). The SIMPER analysis indicated that average dissimilarity among types of vegetation was low (45.9\% for grassland and $32.8 \%$ for shrubland).

TABLE 1. Results of partial RDA analyses of the composition of the arthropod fauna in partially improved heathland grazed by either cattle or sheep, or mixed herds with goats.

\begin{tabular}{|c|c|c|c|c|c|c|c|c|}
\hline Tested hypotheses & Env. & Covar. & Perm. & $\%$ exp. & $F$ first & $P$ first & $F$ all & $P$ all \\
\hline Did the composition of the fauna differ between blocks? & $\mathrm{B} 1$ & & Free/No & 3.4 & & & 0.49 & 0.626 \\
\hline Did the composition of the fauna differ between grazer species? & $\mathrm{Sp}$ & $\mathrm{Bl}, \mathrm{Fl}$ & Free/No & 4.9 & & & 0.61 & 0.113 \\
\hline Did the composition of the fauna differ between grazing regimes? & $\mathrm{Fl}$ & $\mathrm{B} 1, \mathrm{Sp}$ & Free/No & 5.7 & & & 0.72 & 0.058 \\
\hline Did the composition of the fauna differ between vegetation types? & $\mathrm{Vg}$ & $\mathrm{Sp}, \mathrm{Fl}$ & No/Free & 58.0 & & & 16.57 & 0.008 \\
\hline Was the composition of the fauna affected by $\mathrm{Sp} * \mathrm{Fl}$ interaction? & $\mathrm{Sp}^{*} \mathrm{Fl}$ & $\mathrm{B} 1$ & Free/No & 6.9 & 0.82 & 0.336 & 0.55 & 0.173 \\
\hline Was the composition of the fauna affected by $\mathrm{Sp} * \mathrm{Vg}$ interaction? & $\mathrm{Sp}^{*} \mathrm{Vg}$ & & Free/Free & 52.6 & 13.30 & 0.008 & 5.79 & 0.007 \\
\hline Was the composition of the fauna affected by $\mathrm{Fl}^{*} \mathrm{Vg}$ interaction? & $\mathrm{F} l^{*} \mathrm{Vg}$ & & Free/Free & 52.6 & 13.33 & 0.004 & 7.14 & 0.000 \\
\hline
\end{tabular}

Env. - environmental variables; Covar. - covariables; Perm. - permutation at the whole plot / split-plot level; \% exp. - percent of variability explained by the first axis; $F$ first, $P$ first, $F$ all, and $P$ all - values of $F$ and $P$ on the first ordination axis and on all axes, respectively; $\mathrm{Bl}$ - block; $\mathrm{Sp}$ - species of grazer (cattle vs. sheep); Fl - grazing regime (single vs. mixed with goats); $\mathrm{Vg}$ - type of vegetation (gorse-dominated shrubland vs. improved perennial ryegrass-white clover grassland). 


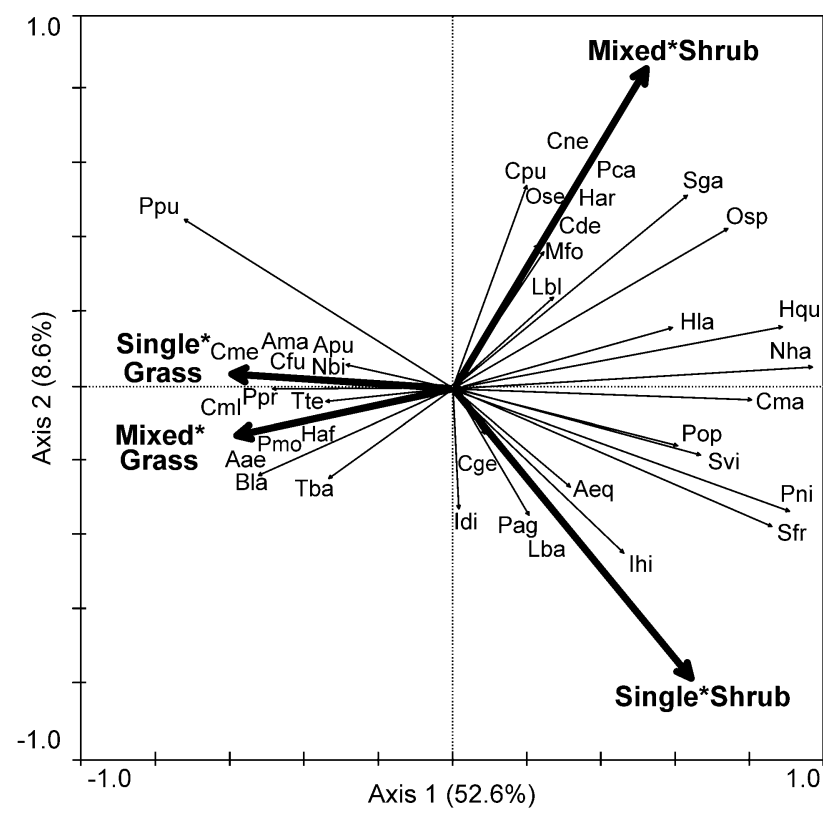

Fig. 3. RDA ordination diagram showing the interaction between grazing regime (single species or mixed herds with goats) and type of vegetation (shrubland or grassland) and their effect on arthropod assemblages. For species abbreviations see appendix.

RDA analyses indicated that the composition of the fauna was also affected by the interaction between grazing regime and type of vegetation $(P<0.01)$. Stepforward selection revealed that shrubland vegetation grazed by mixed flocks with goats $(F=11.61, P<0.001)$ or a single species $(F=5.01, P=0.006)$ accounted for most of the variation in arthropod species composition (52.6\% of the variance of species data). Within shrubland, different groups of species were associated with either grazing by a single species or mixed flocks, whereas faunal assemblages in grassland were similar, irrespective of the grazing regime (Fig. 3).

Subsequent RDA analyses performed for each type of vegetation separately revealed that the composition of the fauna of shrubland was associated with the grazing regime $(36.4 \%$ of variance, $F=2.29, P=0.076)$ and the interaction between species of grazer and grazing regime (40.7\%, $F=2.06, P=0.045)$. The composition of the fauna within that type of vegetation was similar at sites grazed by mixed flocks, irrespective of the species of grazer, whereas different species of arthropods are associated with either grazing only by sheep [e.g. Trechus barnevillei Pandellé, 1867 and Amara equestris (Duftschmid, 1812)] or cattle (e.g. C. macrocephalus and Ischyropsalis hispanica Roewer, 1953) (Fig. 4). According to the SIMPER analysis, around $50 \%$ of the dissimilarity between grazing regimes in shrubland was explained by species such as $S$. franzi (8.5\%), I. hispanica, P. nigriceps (5.5\%) and Phalangium opilio Linnaeus, 1761 (5.3\%), which were more abundant in plots grazed by a single species, and $S$. gallega $(7.6 \%), O$. spinosus (6.2\%), Homalenotus laranderas Grasshoff, $1959(6.1 \%)$ and P. pullata (5.3\%), which were more

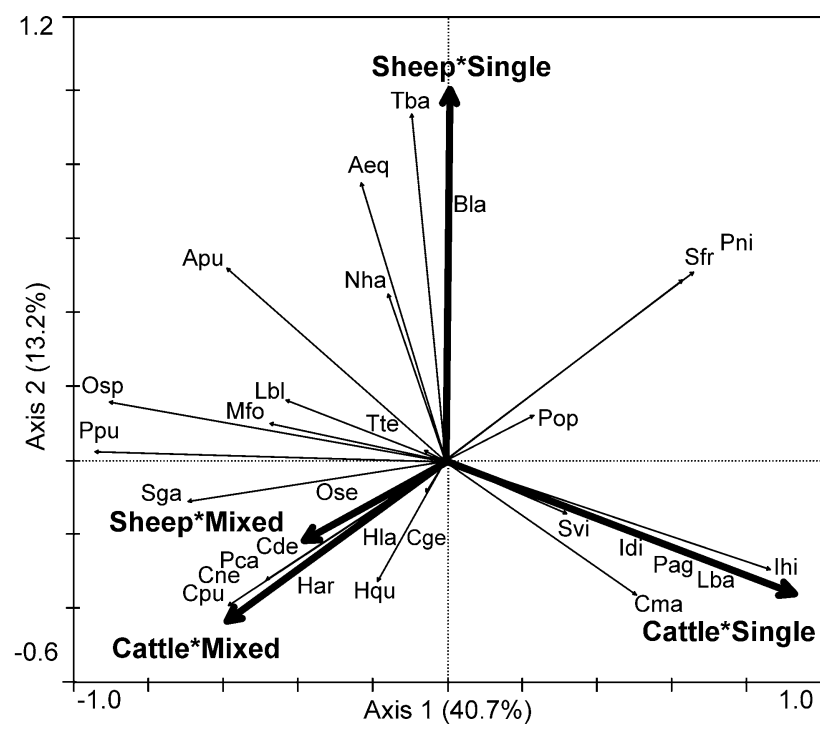

Fig. 4. RDA ordination diagram showing the interaction between species of grazer (cattle or sheep) and grazing regime (single species or mixed herds with goats) and their effect on arthropod assemblages in gorse-dominated shrubland. For species abbreviations see appendix.

abundant in plots grazed by mixed flocks. Unlike the results for shrubland, the RDA analyses of the grassland data revealed that neither the species of grazer nor grazing regime, or their interaction, were significantly associated with the arthropod assemblages.

\section{DISCUSSION}

In the current study, faunal composition was mostly associated with particular types of vegetation rather than species of grazer or grazing regime, although there were significant interactions between vegetation and grazing treatment. It is likely that gorse-dominated shrubland provides a more suitable habitat for more ground-dwelling arthropods, including large beetles (e.g. Carabus spp.) and those species that prefer shrubbier, shadier, moister (e.g. Opiliones) and less altered habitats, than the improved grassland, which is a more suitable habitat for mesophilic (e.g. Amara spp. or Bembidion spp.) and thermophilic taxa (e.g. P. pullata), good colonizers and species characteristic of agro-ecosystems. These patterns have been recorded previously in studies on spiders (Thomas \& Jepson, 1999; Ratschter \& Roth, 2000) and carabids (Pétillon et al., 2007).

The structural complexity of the vegetation was associated with differences in the faunal assemblages in the different types of vegetation as vegetation structure controls the distribution of many taxa (Dennis et al., 2001), along with that of their prey (Otto \& Svensson, 1982), which is probably also affected by the vegetation (Cherret, 1964). Reduced arthropod richness is recorded in simplified agricultural systems (improved pasture or cropping) compared with more complex (wooded or grassland) native systems (Attwood et al., 2008), while a lower species richness of both spiders and ground beetles is reported in scrubby than in herbaceous biotopes located in quarries 
with semi-natural adjacent areas (Tropek et al., 2008). The structure of heathland vegetation is known to affect the occurrence of grasshoppers (Jauregui et al., 2008) and ground-dwelling arthropods (Cuesta et al., 2006, 2008; Rosa García et al., 2009a, b). In the current study, the differences in vegetation structure between shrubland and grassland might have determined their suitability as a habitat for several species.

Multivariate analyses of similarities indicated that the species contributing most to the dissimilarity between types of vegetation were associated with the shrubbier vegetation. This pattern was clear for harvestmen, which were less abundant in improved areas than in shrubland. These arachnids are vulnerable to water loss (Santos, 2007), adapted to narrow ranges of temperature or humidity and are uncommon or absent where climatic conditions are harsh (Almeida-Neto et al., 2006). Their poor dispersal ability, a consequence of their low vagility (Bragagnolo et al., 2007), might have also contributed to their confinement to shrubland areas. Therefore, compared to other groups, harvestmen show quite consistent responses to disturbance (Almeida-Neto et al., 2006; Bragagnolo et al., 2007), a response which was also recorded in this study. Harvestmen were abundant in areas with high shrub cover and uncommon in improved pasture, in agreement with previous studies on sheep and goat grazed Cantabrian heathland, in which more were collected at sites with a high shrub cover than at those with a high cover of herbaceous plants (Rosa García et al., 2009a, 2010). The lycosid $P$. nigriceps was also more abundant in shrubland. This is a woodland or litter dwelling lycosid in western Scotland (Curtis \& Bignal, 1980), associated with open habitats in Ireland and is more abundant in peatland than in improved or wet grassland (Oxbrough et al., 2007). It is recorded from heathland in southern England (Snazell, 1982), northern Ireland (McFerran, 1997) and the north-west of Spain (Rosa-García et al., 2009a, b), and grassland in south-west England (Duffey, 1962) and sand dunes in that country (Duffey, 1968) and in the Netherlands (Vlijm \& Kessler-Geschiere, 1967). According to Entling et al. (2007) it is more associated with open habitats than shaded ones (forests), although it also occurs more frequently in moister habitats rather than in drier ones in central Europe. It prefers tall (McFerran, 1997), dense vegetation (Bonte et al., 2000; Snazell, 1982) with a closed canopy (Pétillon \& Garbutt, 2008). The habitats dominated by shrubs were also preferred by C. macrocephalus, a reliable indicator of the effects of $\mathrm{N}$ deposition in heathland in NW Spain (Cuesta et al., 2008), where it is favoured by the development of a denser and more complex vegetation (Cuesta et al., 2006; Rosa García et al., 2009b). In fact, it prefers woodland and shrubland in the Cantabrian Mountains, where it occupies humid microenvironments (Peláez \& Salgado, 2007). In contrast, other taxa preferred grassland areas, like $P$. pullata or $T$. terricola, which are also more abundant in Cantabrian heathland with a higher herbaceous cover than that with a higher shrub cover (Rosa García et al., 2009a, 2010). Pardosa pullata is associated with open habitats (Oxbrough et al., 2007) and is one of the most highly invasive and stress tolerant European spiders common in grassland and heathland (Bell et al., 2001). It can withstand the high temperatures and humidity experienced on Danish bogs (Nørgaard, 1951) and is also common on wet heath and bog in Northern Ireland (McFerran, 1997). It seems to prefer taller, fescue dominated grassland (Duffey, 1962), but occurs in all types of grassland in upland limestone environments in Britain (Bell et al., 1998) and abounds in shorter vegetation in north-east Ireland (McFerran et al., 1994). Trochosa terricola is a habitat generalist (Oxbrough et al., 2007) common in open localities in Northern Ireland heathland (McFerran, 1997). It is more abundant on heather moorlands, but also found on grassland (Cameron et al., 2004) where it hunts prey and mates in the short-grazed vegetation (Bonte et al., 2000).

When considered in isolation, species of grazer (cattle or sheep) and grazing regime (single species or mixed flocks with goats) were weakly associated with the species composition of the arthropod fauna and there were significant interactions between these factors and the type of vegetation. Thus, while grazing regime was more important for the fauna in shrubland, the species of grazer was associated with different sets of species in the improved areas, although the overall sensitivity of the fauna was lower than in shrubland. Sward height was broadly similar between plots in the improved areas, so structural and microclimatic conditions might not be different enough for certain species to be associated with one grazer or another, and others are adapted to stress or frequently occur on heliophil and xerophil sites in agricultural areas (Nyffeler \& Breene, 1992). Warui et al. (2005) indicate that the presence of large herbivores (and especially cattle) in a Kenyan savanna biome affected spiders indirectly by reducing vegetation cover, but the species of ground-dwelling spiders were similarly associated with the different herbivore groups and seemed less affected by changes in the vegetation than foliage dwelling species. In the current study the arrangement of the plots might have also influenced the responses within grassland due to spatial autocorrelation, although plot size was considered adequate for determining the effect of the treatments on the fauna.

Nevertheless, cattle contribute to the maintenance of vegetation structural diversity and arthropod abundance and diversity in upland grassland as they are less selective when grazing than sheep (Dennis et al., 2008). As a result, there are more patches of tall vegetation at cattle than sheep grazed sites and sward height is important for taxa such as spiders (Bell et al., 2001; Dennis et al., 2001), especially web building species (Curry, 1994). In contrast, large carabids are less abundant at sheep and cattle grazed sites than at those only grazed by sheep, possibly because of the higher soil compaction or the disturbance due to treading by cattle (Dennis, 2003). Finally, changes in the dung beetle fauna are recorded in pastureland where the replacement of sheep by cattle resulted in the deposition of a more hydrated, abundant and less 
ephemeral resource in the form of cow dung (Lumaret et al., 1992).

Grazing regime accounted for a great part of the variance in arthropod species composition of shrubland as goats spend longer (up to $68 \%$ of the grazing time) in the scrub than the other species of livestock and reduced the encroachment by gorse to a greater extent than grazing by only either sheep or cattle (Benavides et al., 2009). Mixed grazing resulted in the reduction in the number of arthropod species that occupy shrubby, moist and shaded environments [e.g. harvestmen like I. hispanica or Paroligolophus agrestis (Meade, 1855)], whereas some carabids (e.g. S. gallega or Carabus purpurascens Fabricius, 1787) and certain opilionid species (e.g. O. spinosus), which might be more xerothermophilous (Zahn et al., 2007), were favoured. Dennis et al. (2008) record higher total arthropod biomass and higher abundances of spiders and beetles at sites grazed by both cattle and sheep than at those grazed only by sheep, although according to Bell et al. (2001) mixed grazing by sheep and cattle may promote the development of uniform swards adequate for certain spider species, while others prefer the more open heterogeneous swards that develop when grazed by a single species. Nevertheless, most studies are focused on the effect of mixed grazing by cattle and sheep on grassland and there are no studies on the effect of mixed flocks, including goats, in areas where there is both shrubland and grassland. Although goats are not commonly used for managing heathland in the United Kingdom, there is an increasing interest in their use for nature conservation (Lake et al., 2001). The current study indicates their important role in managing shrubland, as their grazing was clearly associated with the faunal assemblages, and a lesser role in grasslands, probably due to their preference for browsing (Benavides et al., 2009).

In conclusion, general assumptions about whether management by grazing is beneficial or not should be considered carefully, as the same grazing treatment might have different effects depending on the environmental context, particularly the structure of the vegetation. Most of the variability in faunal assemblages was due to differences in the vegetation. Fauna typical of shrubby and moist environments mostly occurred in the gorse-dominated shrubland, whereas certain species, mostly the least sensitive, which are of low conservation concern, occurred mainly in sown grassland despite its less complex vegetation structure. The species of grazer (cattle or sheep) accounted for a small amount of the variance when the only explanatory variable. The presence of goats in a flock had a low effect on the fauna in grassland but generated a greater environmental heterogeneity in shrubland, which provides a greater range of microclimatic conditions suitable for a wider variety of ground-dwelling arthropods.

ACKNOWLEDGEMENTS. We thank to the team working at the experimental farm for their support and efficient management. This study was funded by the Spanish National Institute for Agricultural Research (INIA, project RTA-01-014-C2-1) and the Spanish Interministry Commission for Science and Technology (CICYT, project AGL2003-05342).

\section{REFERENCES}

Almeida-Neto M., Machado G., Pinto-Da-Rocha R. \& GiaRetTA A.A. 2006: Harvestmen (Arachnida: Opiliones) species distribution along three Neotropical elevational gradients: an alternative rescue effect to explain Rapoport's rule? J. Biogeogr. 33: 361-375.

Álvarez M.A., García P. \& Valderrábano J. 2004: Tipificación, Cartografia y Evaluación de los Pastos Españoles: Cartografia de los Pastos de Asturias. SEEP-INIA-SERIDAINDUROT, Oviedo, 138 pp.

Attwood S.J., Maron M., House A.P.N. \& Zammit C. 2008: Do arthropod assemblages display globally consistent responses to intensified agricultural land use and management? Global Ecol. Biogeogr. 17: 585-599.

Bell J.R., Cullen W.R. \& Wheater C.P. 1998: The structure of spider communities in limestone quarry environments. In Selden P.A. (ed.): Proceedings of the 17th European Colloquium of Arachnology. British Arachnological Society, Burnham Beeches, Bucks., pp. 253-259.

Bell J.R., Wheater C.P. \& Cullen W.R. 2001: The implications of grassland and heathland management for the conservation of spider communities: a review. J. Zool. 255: 377-387.

Benavides R., Celaya R., Ferreira L.M.M., Jáuregui B.M., García U. \& Osoro K. 2009: Grazing behaviour of domestic ruminants according to flock type and subsequent vegetation changes on partially improved heathlands. Span. J. Agric. Res. 7: 417-430.

Bignal E.M. 1998: Using an ecological understanding of farmland to reconcile nature conservation requirements, EU agriculture policy and world trade agreements J. Appl. Ecol. 35: 949-954.

Bonte D., Maelfait J.P. \& Hoffmann M. 2000: The impact of grazing on spider communities in a mesophytic calcareous dune grassland. J. Coastal Conserv. 6: 135-144.

Bragagnolo C., Nogueira A.A., Pinto-Da-Rocha R. \& Pardini R. 2007: Harvestmen in an Atlantic forest fragmented landscape: Evaluating assemblage response to habitat quality and quantity. Biol. Conserv. 139: 389-400.

Bromham L., Cardillo M., Bennett A.F. \& Elgar M.A. 1999: Effects of stock grazing on the ground invertebrate fauna of woodland remnants. Aust. J. Ecol. 24: 199-207.

Cameron A., Johnston R.J. \& McAdam J. 2004: Classification and evaluation of spider (Araneae) assemblages on environmentally sensitive areas in Northern Ireland. Agric. Ecosyst. Environ. 102: 29-40.

Cardoso P., Silva I., Oliveira N.G. \& Serrano A.R.M. 2004: Higher taxa surrogates of spider (Araneae) diversity and their efficiency in conservation. Biol. Conserv. 120: 453-459.

Celaya R., Martínez A. \& Osoro K. 2007: Vegetation dynamics in Cantabrian heathlands associated with improved grassland areas under single or mixed grazing by sheep and goats. Small Rumin. Res. 72: 165-177.

Celaya R., Benavides R., García U., Ferreira L.M.M., Ferre I., Martínez A., Ortega-Mora L.M. \& Osoro K. 2008: Grazing behaviour and performance of lactating suckler cows, ewes and goats on partially improved heathlands. Animal 2: $1818-1831$.

Cherret J.M. 1964: The distribution of spiders on the Moor House Nature Reserve, Westmorland. J. Anim. Ecol. 33: $27-48$. 
Clarke K.R. \& Gorley R.N. 2001: PRIMER v5: User Manual/Tutorial. PRIMER-E, Plymouth, $91 \mathrm{pp}$.

Clarke K.R. \& Warwick R.M. 2001: Change in Marine Community: An Approach to Statistical Analysis and Interpretation. Plymouth Marine Laboratory, Plymouth, $172 \mathrm{pp}$.

Cuesta D., Taboada A., Calvo L. \& Salgado J.M. 2006: A preliminary investigation of ground beetle (Coleoptera: Carabidae) assemblages and vegetation community structure in Calluna vulgaris heathlands in NW Spain. Entomol. Fenn. 17: $241-252$.

Cuesta D., Taboada A., Calvo L. \& Salgado J.M. 2008: Shortand medium-term effects of experimental nitrogen fertilization on arthropods associated with Calluna vulgaris heathlands in north-west Spain. Environ. Pollut. 152: 394-402.

CurTis D.J. \& Bignal E.M. 1980: Variations in peat-bog spider communities in relation to environmental heterogeneity. In Proceedings of the 8th International Congress of Arachnology. Vienna, pp. 81-86.

CURRY J.P. 1994: Grassland Invertebrates. Ecology, Influence on Soil Fertility and Effects on Plant Growth. Chapman and Hall, London, 437 pp.

Decaens T., Jiménez J.J., Barros E., Chauvel A., Blanchart E. Fragoso C. \& Lavelle P. 2004: Soil macrofaunal communities in permanent pastures derived from tropical forest or savanna. Agric. Ecosyst. Environ. 103: 301-312.

DenNIS P. 2003: Sensitivity of upland arthropod diversity to livestock grazing, vegetation structure and landform. J. Food Agr. Environ. 1: 301-307.

Dennis P., Young M.R., Howard C.L. \& Gordon I.J. 1997: The response of epigeal beetles (Col.: Carabidae, Staphylinidae) to varied grazing regimes on upland Nardus stricta grasslands. J. Appl. Ecol. 34: 433-443.

Dennis P., Young M.R. \& Bentley C. 2001: The effects of varied grazing management on epigeal spiders, harvestmen and pseudoscorpions of Nardus stricta grassland in upland Scotland. Agric. Ecosyst. Environ. 86: 39-57.

Dennis P., Skartveit J., McCracken D.I., Pakeman R.J., Beaton K., Kunaver A. \& Evans D.M. 2008: The effects of livestock grazing on the foliar arthropods associated with bird diet in upland grasslands of Scotland. J. Appl. Ecol. 45: 279-287.

DufFey E. 1962: A population study of spiders in limestone grassland. The field-layer fauna. Oikos 13: 15-34.

DufFEY E. 1968: An ecological analysis of the spider fauna of sand dunes. J. Anim. Ecol. 37: 571-599.

Entling W., Schmidt M.H., Bacher S., Brandl R. \& Nentwig W. 2007: Niche properties of Central European spiders: shading, moisture and the evolution of the habitat niche. Global Ecol. Biogeogr. 16: 440-448.

GRANT S.A. 1981: Sward components. In Hodgson J., Baker R.D., Davies A., Laidlaw A.S. \& Leaver J.D. (eds): Sward Measurement Handbook. British Grassland Society, Hurley, Maidenhead, Berks., pp. 71-92.

Harvey P.R., Nellist D.R. \& Telfer M.G. (eds) 2002: Provisional Atlas of British Spiders (Arachnida, Araneae). Vol. 1 \& 2. Biological Records Center, Huntingdon, 406 pp.

Jauregui B.M., Rosa Garcia R., Garcia U., WallisDeVries M.F., Osoro K. \& Celaya R. 2008: Effects of stocking density and breed of goats on vegetation and grasshopper occurrence in heathlands. Agric. Ecosyst. Environ. 123: 219-224.

Kleijn D., Baquero R.A., Clough Y., Díaz M., De Esteban J., Fernández F., Gabriel D., Herzog F., Holzschuh A., Jöhl R., Knop E., Kruess A., Marshall E.J.P., Steffan-Dewenter I., TscharntKe T., Verhulst J., West T.M. \& Yela J.L. 2006: Mixed biodiversity benefits of agri-environment schemes in five European countries. Ecol. Lett. 9: 243-254.
Komposch C. 2004: The harvestman fauna of Hungary (Arachnida, Opiliones). In Samu F. \& Szinetár C. (eds): European Arachnology 2002. Plant Protection Institute, Hungarian Academy of Sciences, Budapest, Berzsenyi Dániel College, Szombathely, pp. 227-242.

Kremen C. 1992: Assessing the indicator properties of species assemblages for natural areas monitoring. Ecol. Appl. 2: 203-217.

Kremen C., Colwell R.K., Erwin T.L., Murphy D.D., Noss R.F. \& SANJAYAn M.A. 1993: Terrestrial arthropod assemblages their use in conservation planning. Conserv. Biol. 7: 796-808.

LaKe S., Bullock J.M. \& HarveY S. 2001: Impacts of Livestock Grazing on Lowland Heathland in UK. English Nature, Research Report 422, Peterborough, UK, 143 pp.

LEPŠ J. \& ŠMILAUER P. 2003: Multivariate Analysis of Ecological Data Using CANOCO. Cambridge University Press, Cambridge, $269 \mathrm{pp}$.

Lumaret J.P., Kadiri N. \& Bertrand M. 1992: Changes in resources: consequences for the dynamics of dung beetle communities. J. Appl. Ecol. 29: 349-356.

MarRS R. \& Britton A. 2000: Conservation problems on Breckland heaths: from theory to practice. Biol. Conserv. 95: 143-151.

McFerRan D. 1997: Northern Ireland Species Inventories. Spiders (Arachnida). Queen University Belfast, Belfast, 51 pp.

McFerran D.M., Montgomery W.I. \& McAdam J.H. 1994: The impact of grazing on communites of ground dwelling spiders (Araneae) in upland vegetation types. Biol. Environ. 94: 119-126.

NIEMELÄ J. 2000: Biodiversity monitoring for decision-making. Ann. Zool. Fenn. 37: 307-317.

NøRGaArd E. 1951: On the ecology of two lycosid spiders (Pirata piraticus and Lycosa pullata) from a Danish sphagnum bog. Oikos 3: 1-21.

NyfFeleR M. \& BREENE R.G. 1992: Dominant insectivorous polyphagous predators in winter wheat: high colonization power, spatial dispersion patterns and probable importance of the soil surface spiders (Araneae). Dt. Entomol. Z. 39: 177-188.

Ortuño V.M. \& Marcos J.M. 2003: Los Caraboidea (Insecta: Coleoptera) de la Comunidad Autónoma del País Vasco (I). Servicio Central de Publicaciones del Gobierno Vasco, Vitoria, $573 \mathrm{pp}$.

Osoro K, García U., Jáuregui B.M., Ferreira L.M.M., Rook A.J. \& Celaya R. 2007: Diet selection and live-weight changes of two breeds of goats grazing on heathlands. Animal 1: 449-467.

OSTERMANN O.P. 1998: The need for management of nature conservation sites designated under Natura 2000. J. Appl. Ecol. 35: 968-973.

Отто C. \& Svensson B.S. 1982: Structure of communities of ground-living spiders along altitudinal gradients. Holarctic Ecol. 5: 35-47.

Oxbrough A.G., Gittings T., O’Halloran J., Giller P.S. \& Kelly T.C. 2006: The initial effects of afforestation on the ground-dwelling spider fauna of Irish peatlands and grasslands. For. Ecol. Manag. 237: 478-491.

Oxbrough A.G., Gittings T., O'Halloran J., Giller P.S. \& Kelly T.C. 2007: Biodiversity of the ground-dwelling spider fauna of afforestation habitats. Agric. Ecosyst. Environ. 120: 433-441.

Pearce J.L. \& Venier L.A. 2006: The use of ground beetles (Coleoptera: Carabidae) and spiders (Araneae) as bioindicators of sustainable forest management: a review. Ecol. Indicat. 6: 780-793. 
Peláez M.C. \& Salgado J.M. 2007: Ecología y biología de algunas especies de Carabidae (Coleoptera) del macizo del Sueve (Asturias): estudios fenológico y de fluctuación anual. Bol. S.E.A. 40: 333-350.

Pétillon J. \& Garbutt A. 2008: Success of manager realignment for the restoration of salt-marsh biodiversity: preliminary results on ground-active spiders. J. Arachnol. 36: 388-393.

Pétillon J., Georges A., Canard A. \& Ysnel F. 2007: Impact of cutting and sheep grazing on ground-active spiders and carabids in intertidal salt marshes (Western France). Anim. Biodivers. Conserv. 30: 201-209.

Platnick N.I. 2006: The World Spider Catalogue (Version 7.0). American Museum of Natural History. Available at: http://research.amnh.org/entomology/spiders/catalog/index.ht ml. Visited on 23.xi.2006.

Plieninger T., Höchtl F. \& Spek T. 2006: Traditional land-use and nature conservation in European landscapes. Environ. Sci. Policy 9: 317-321.

RaINIO J. \& NIEMELÄ J. 2003: Ground beetles (Coleoptera: Carabidae) as bioindicators. Biol. Conserv. 12: 487-506.

Rambla M. 1998: Opiliones (Arachnida) presentes en la fauna aragonesa. Cat. Entomol. Aragonesa 17: 3-7.

Ratschter U.M. \& Roth M. 2000: Studies on ground dwelling spiders (Araneae) of agrarian habitat types in northeast Germany: ecological and nature conservation aspects. Ekologia (Bratislava) 19: 213-225.

Rosa García R., Jáuregui B.M., García U., Osoro K. \& Celaya R. 2009a: Effects of livestock breed and grazing pressure on ground-dwelling arthropods in Cantabrian heathlands. Ecol. Entomol. 34: 466-475.

Rosa García R., Jáuregui B.M., García U., Osoro K. \& Celaya R. 2009b: Responses of arthropod fauna assemblages to goat grazing management in northern Spanish heathlands. Environ. Entomol. 38: 985-995.

Rosa García R., Ocharan F.J., Jáuregui B.M., García U., Osoro K. \& Celaya R. 2010: Ground-dwelling arthropod communities present in three types of Cantabrian (NW Spain) heathland grazed by sheep or goats. Eur. J. Entomol. 107: 219-227.
Rose R.J., Webb N.R., Clarke R.T. \& Traynor C.H. 2000: Changes on the heathlands in Dorset, England, between 1987 and 1996. Biol. Conserv. 93: 117-125.

SAnTOS F.H.S. 2007: Ecophysiology. In Pinto-da-Rocha R., Machado G. \& Giribert G. (eds): Harvestmen: The Biology of Opiliones. Harvard University Press, Cambridge, MA, pp. 473-488.

Sineiro F., Osoro K. \& Díaz N. 1984: Bases para la producción e intensificación ganadera en el monte gallego: la utilización de la vegetación espontánea y la siembra y mejora del pasto. In Pastos y Forrajes en Alimentación Animal. Actas de la XXII Reunión Científica de la Sociedad Ibérica de Nutrición Animal. SINA, Santiago de Compostela, pp. 195-219.

SNAZELL R. 1982: Habitat preferences of spiders on heathland in southern England. Bull. Br. Arachnol. Soc. 5: 352-360.

Ter Braak C.J.F. \& Šmilauer P. 2002: CANOCO Reference Manual and User's Guide to Canoco for Windows Software for Canonical Community Ordination (Version 4.5). Microcomputer Power, Ithaca, NY, 500 pp.

Thomas C.F.G. \& Jepson P.C. 1999: Differential aerial dispersal of linyphiid spiders from grass and a cereal field. J. Arachnol. 27: 294-300.

Tropek R., Spitzer L. \& KonvičKa M. 2008: Two groups of epigeic arthropods differ in colonising of piedmont quarries: the necessity of multi-taxa and life-history traits approaches in the monitoring studies. Comm. Ecol. 9: 177-184.

Vlijm L. \& Kessler-Geschiere A.M. 1967: The phenology and habitat of Pardosa monticola, P. nigriceps and P. pullata (Araneae: Lycosidae). J. Anim. Ecol. 36: 31-56.

Warui C.M., Villet M.H., Young T.P. \& Jocqué R. 2005: Influence of grazing by large mammals on the spider community of a Kenyan savanna biome. J. Arachnol. 33: 269-279.

WeBB N.R. 1990: Changes on the heathlands of Dorset, England, between 1978 and 1987. Biol. Conserv. 51: $273-286$.

Zahn A., Juen A., Traugott M. \& Lang A. 2007: Low density cattle grazing enhances arthropod diversity of abandoned wetland. Appl. Ecol. Environ. Res. 5: 73-86.

Received April 13, 2010; revised and accepted July 20, 2010

ApPendix. Species of Araneae, Opiliones and Coleoptera captured in partially improved heathland with different types of vegetation (shrubland or grassland), species of grazer (cattle or sheep) and grazing regime ( $\mathrm{S}$ - single; $\mathrm{M}$ - mixed with goats). Catches for two plots per treatment were pooled (six pitfall traps per plot within each type of vegetation).

\begin{tabular}{|c|c|c|c|c|c|c|c|c|c|}
\hline \multirow{3}{*}{$\begin{array}{l}\text { Vegetation type } \\
\text { Grazer species } \\
\text { Flock type }\end{array}$} & \multirow{3}{*}{ Abbrev. ${ }^{1}$} & \multicolumn{4}{|c|}{ Shrubland } & \multicolumn{4}{|c|}{ Grassland } \\
\hline & & \multicolumn{2}{|c|}{ Cattle } & \multicolumn{2}{|c|}{ Sheep } & \multicolumn{2}{|c|}{ Cattle } & \multicolumn{2}{|c|}{ Sheep } \\
\hline & & $\mathrm{S}$ & $\mathrm{M}$ & $\mathrm{S}$ & $\mathrm{M}$ & $\mathrm{S}$ & $\mathrm{M}$ & $\mathrm{S}$ & $\mathrm{M}$ \\
\hline \multicolumn{10}{|l|}{ O. Araneae } \\
\hline Alopecosa pulverulenta (Clerck, 1758) & Apu & 0 & 1 & 2 & 2 & 1 & 5 & 2 & 3 \\
\hline Pardosa monticola (Clerck, 1758) & Pmo & 0 & 0 & 0 & 0 & 0 & 1 & 0 & 0 \\
\hline Pardosa nigriceps (Thorell, 1856) & Pni & 18 & 6 & 19 & 5 & 0 & 0 & 0 & 1 \\
\hline Pardosa proxima (C.L. Koch, 1847) & Ppr & 0 & 0 & 0 & 0 & 2 & 1 & 2 & 0 \\
\hline Pardosa pullata (Clerck, 1758) & Ppu & 4 & 28 & 14 & 21 & 38 & 25 & 57 & 45 \\
\hline Trochosa terricola (Thorell, 1856) & Tte & 7 & 3 & 4 & 7 & 2 & 10 & 8 & 31 \\
\hline \multicolumn{10}{|l|}{ O. Opiliones } \\
\hline Homalenotus laranderas Grasshoff, 1959 & Hla & 7 & 3 & 5 & 15 & 0 & 1 & 0 & 0 \\
\hline Homalenotus quadridentatus (Cuvier, 1795) & $H q u$ & 30 & 34 & 20 & 28 & 0 & 2 & 4 & 0 \\
\hline Ischyropsalis hispanica Roewer, 1953 & $I h i$ & 26 & 0 & 1 & 3 & 0 & 1 & 0 & 1 \\
\hline Leiobunum blackwalli Meade, 1861 & $L b l$ & 0 & 1 & 1 & 1 & 0 & 0 & 1 & 0 \\
\hline Nemastoma hankiewiczii (Kulczynski, 1909) & Nha & 64 & 57 & 95 & 81 & 3 & 1 & 1 & 2 \\
\hline Odiellus seoanei (Simon, 1878) & Ose & 0 & 0 & 0 & 1 & 0 & 0 & 0 & 0 \\
\hline
\end{tabular}


Odiellus spinosus (Bosc, 1792)

Paroligolophus agrestis (Meade, 1855)

Phalangium opilio Linnaeus, 1761

Sabacon franzi Roewer, 1953

O. Coleoptera

Amara equestris (Duftschmid, 1812)

Amara aenea (De Geer 1774)

Amara sp.

Bembidion lampros (Herbst, 1784)

Calathus fuscipes (Goeze, 1777)

Calathus melanocephalus (Linnaeus, 1758)

Carabus deyrollei Gory, 1839

Carabus getschmanni Lapouge, 1924

Carabus macrocephalus Dejean, 1826

Carabus melancholicus Fabricius, 1798

Carabus nemoralis O.F. Müller, 1764

Carabus purpurascens Fabricius, 1787

Harpalus affinis (Schrank, 1781)

Harpalus sp.

Iberodinodes dives Dejean, 1826

Leistus barnevillei Chaudoir, 1867

Metabletus foveatus (Geoffroy, 1785)

Pterostichus cantaber (Chaudoir, 1868)

Steropus gallega (Fairmaire, 1859)

Synuchus vivalis (Illiger, 1798)

Trechus barnevillei Pandellé, 1867
Notiophilus biguttatus (Fabricius, 1779)

\begin{tabular}{|c|c|c|c|c|c|c|c|c|}
\hline Osp & 2 & 28 & 15 & 16 & 2 & 1 & 0 & 0 \\
\hline Pag & 9 & 0 & 0 & 0 & 1 & 0 & 0 & 0 \\
\hline Pop & 7 & 2 & 6 & 2 & 0 & 0 & 0 & 0 \\
\hline$S f r$ & 64 & 3 & 43 & 11 & 0 & 0 & 0 & 0 \\
\hline Aeq & 0 & 2 & 5 & 0 & 0 & 1 & 0 & 1 \\
\hline Aae & 0 & 0 & 0 & 0 & 0 & 1 & 0 & 2 \\
\hline Ama & 0 & 0 & 0 & 0 & 1 & 0 & 0 & 0 \\
\hline Bla & 0 & 0 & 1 & 0 & 1 & 2 & 1 & 2 \\
\hline$C f u$ & 0 & 0 & 0 & 0 & 1 & 0 & 0 & 0 \\
\hline Cme & 0 & 0 & 0 & 0 & 1 & 0 & 0 & 0 \\
\hline Cde & 0 & 1 & 0 & 0 & 0 & 0 & 0 & 0 \\
\hline Cge & 1 & 2 & 1 & 0 & 0 & 2 & 0 & 1 \\
\hline $\mathrm{Cma}$ & 101 & 60 & 44 & 50 & 9 & 21 & 11 & 7 \\
\hline $\mathrm{Cml}$ & 0 & 0 & 0 & 0 & 0 & 1 & 0 & 0 \\
\hline Cne & 0 & 1 & 0 & 1 & 0 & 0 & 0 & 0 \\
\hline Сри & 0 & 3 & 0 & 2 & 0 & 2 & 0 & 0 \\
\hline Haf & 0 & 0 & 0 & 0 & 0 & 1 & 0 & 0 \\
\hline Har & 0 & 1 & 0 & 0 & 0 & 0 & 0 & 0 \\
\hline$I d i$ & 1 & 0 & 0 & 0 & 0 & 1 & 0 & 0 \\
\hline$L b a$ & 1 & 0 & 0 & 0 & 0 & 0 & 0 & 0 \\
\hline$M f_{o}$ & 0 & 1 & 2 & 6 & 0 & 1 & 1 & 1 \\
\hline$N b i$ & 0 & 0 & 0 & 0 & 1 & 0 & 0 & 0 \\
\hline$P c a$ & 0 & 1 & 0 & 1 & 0 & 0 & 0 & 0 \\
\hline$S g a$ & 1 & 27 & 5 & 27 & 0 & 0 & 1 & 0 \\
\hline$S v i$ & 4 & 4 & 2 & 0 & 0 & 0 & 1 & 0 \\
\hline$T b a$ & 0 & 0 & 5 & 1 & 2 & 0 & 10 & 5 \\
\hline
\end{tabular}

${ }^{1}$ Abbreviations used in the RDA ordination diagrams (Figs 2, 3 and 4). 